\title{
Scientific Administration and the Question of Efficiency
}

\begin{abstract}
This chapter delves into the import and development of American scientific management for both business management and public administration education in postindependence Indonesia. Indonesian realization of its managerial and administrative limits came from the failure of the country's first industrialization plan, the Sumitro Plan, published in 1951. The creation of management and administration education was assisted by the consult of American management experts who visited the country in the mid-1950s with USAID money. This process of legitimizing the role of managers and the managerial class was criticized by people like Ernst Utrecht which saw the belief of scientific management as panacea to Indonesia's administrative woes as unwarranted. The dangers of scientific management and the managerial state ideology it engendered were rooted in its anti-liberal and anti-democratic stance. Scientific management became an ideology that legitimized the creation of a welfare state in which administrative efficiency would trump political rights. It placed administrative efficiency as a paramount goal of the state. America's managerial ideology was thus instrumental in supporting the rise of the New Order's corporatist, familial state, whose foundations were developed in the context of Sukarno's Guided Democracy state. The merging of the corporatist and developmental state was bridged through the ideology of scientific management.
\end{abstract}

\section{Keywords}

scientific management - managerial ideology - corporatist ideology - gotong royong

Like national planning, scientific administration was new in the sense that although colonial antecedents existed, the incorporation of American ideas provided new ways of dealing with state-society relations. And, like national planning, scientific management was part of the international aid structure provided by the US to newly independent states across the world. Scientific management provided the trappings of efficiency and efficacy that were 
alluring to the elites of these new post-colonial nations. In its incarnation within Indonesia, the ideas of efficiency would be implemented at many levels across the state and its economy.

The rise of administration science would result in the formation of a series of institutions within the universities and the creation of specialized learning institutions to provide education and research and to develop a specifically Indonesian type of public administration. Within the Indonesian economy there were two major drives in the 1950s. The first was the development of business administration science, which was to provide the managerial manpower needs of business offices. Public and business management were two sides of the same coin. However, despite this similarity, both developed separately in Indonesia within differing institutional environments. Public administration science developed in the corridors of social and political science faculties, while business administration was developed as part of the economics faculty. The development of scientific management deeply affected the decolonization process for two reasons. First, it entailed Americanization, which provided the means to leave behind Dutch, that is, liberal, ways of doing things. Second, and related to this, was the relationship between managerial science and the legitimacy of the Guided Democracy. It would not be too wrong to say that the idea of efficiency contributed to the end of parliamentary democracy in Indonesia.

\section{Development of Management}

Public administration developed from the confines of political science, while scientific management developed from that of engineering. Both were predicated on the idea of producing professional, white-collar experts for the government office and the factory floor. Administrative experts were seen as the implementers of efficiency, which was central to the most important goal of the twentieth-century state: development. In the words of public administration expert Donald C. Stone: 'The primary obstacle to development is administrative rather than economic [...] Countries generally lack the administrative capability for implementing plans and programmes. Countries share in common most of the same administrative problems and obstacles.' ${ }^{.1}$ Although modern business management had developed rapidly before the Second World War, the science of what came to be known as public administration was still in

1 Donald C. Stone, 'Government Machinery Necessary for Development', quoted in William J. Siffin, 'Two Decades of Public Administration in Developing Countries', Public Administration Review, 36/1 (January/February 1976), 62. 
its gestation period. It was one of the primary exports of American scientific achievement that was channelled through the Marshall Plan and the various American aid programmes. In 1955, Americans started exporting the nascent science around the world. It was a science still under development, as William J. Siffin explains: 'Defining the subject was less an issue than doing it, studying it and exporting it, whatever it might be.'2 From 1955 to 1963 , American aid to assist with public administration totalled $\$ 187$ million and between $195^{2}$ and 1963, around six thousand people from all over the world were sent to the US for training, courtesy of the ICA. The UN, the Ford Foundation, and the US government helped to establish some seventy public administration training institutions in various developing countries. ${ }^{3}$

In East Asia, the interest in promoting public administration was clear early on. The report of the Economic Survey Mission to Southeast Asia (the Griffin Mission) in 1950 had concluded that there was a need to support public administration in Indonesia. Formal recognition of this came with the Bell Mission to the Philippines. ${ }^{4}$ US economic assistance to the region in the period 1948 1967 totalled $\$ 7.6$ billion. Technical cooperation amounted to $\$ 522.2$ million, or roughly 7.3 per cent of the total. Of that, only $\$ 33.7$ million, or half a per cent, was spent on public administration. In Indonesia, that amounted to $\$ 6.1$ million. The countries of Indonesia, Thailand, Korea, and the Philippines received 88 per cent of the total aid spent on public administration in East Asia. ${ }^{5}$

From 1952 to 1965 , the ECA sent 502 Indonesian trainees to the US to study public administration. The ECA helped to establish a series of public administration organizations, including the Public Service Centre (Balai Pelatihan Administrasi) at Gadjah Mada University, the Local Government Training Academy (Akademi Pemerintahan Dalam Negeri), and the National Institute of Administration (Lembaga Administrasi Negara). In the period 1957-1965, USAID ran seven projects in public administration - four focused on training and three others on fiscal management, central-government administration, and local government. ${ }^{6}$ The United States would help to create twelve public administration institutions in East Asia, ten of which were assisted through direct contracts with American universities. ${ }^{7}$

2 Siffin, 'Two Decades of Public Administration', 61.

3 Siffin, 'Two Decades of Public Administration', 66.

4 Frank M. Landers and Harry W. Marsh, United States Technical Assistance in Public Administration in East Asia (New York: The East Asia Society, 1968), 2.

5 Landers and Marsh, United States Technical Assistance in Public Administration, 4.

6 Landers and Marsh, United States Technical Assistance in Public Administration, 13.

7 Landers and Marsh, United States Technical Assistance in Public Administration, 4-6. 
The push to implement scientific management was the result of the failure of a series of state-based industrialization efforts within the Economic Urgency Plan (Rentjana Urgensi Perekonomian) and the Benteng Programme. The plan started in 1951. The Urgency or Sumitro Plan outlined the need to improve and expand the research and training institutes of the Department of Industries (Departmen Perindustrian); to extend loans and credit to cottage and smallscale industries; to establish, through direct government sponsorship, central production and processing units (induk perusahaan) in industrial centres; and to establish government-sponsored, large-scale industrial plants in sectors of vital importance. In 1954, under orders from the National Planning Bureau (BPN) and the Department of Industry of the Ministry of Economic Affairs (Departemen Perindustrian Kementerian Urusan Perekonomian), Sumitro Djojohadikusumo appointed the LPEM, the research arm of the Faculty of Economics, Universitas Indonesia, to conduct research into the industrialization efforts in the country. The findings emphasized the need to build up both the public and the business administration in the country, if a state-based industrialization programme was to be developed. ${ }^{8}$

The Sumitro Plan made little progress after its inception in 1951. Projects that were supposed to have been ready by the end of $195^{2}$ were, for the greater part, still not completed by the middle of 1954. This was due to poor organization as a result of incompetent management and a lack of experience, a shortage of expert and experienced labour, and unattractive wages for technicians and management. From the government side, bureaucracy hindered instead of helped as a result of various administrative and financial regulations. There was a lack of coordination between the government departments and, at a lower level, between the departments and the project managers. This illustrated the sad state of the public administration. Lastly, there was a general lack of technical experts in the government. ${ }^{9}$

The Induk Perusahaan programme met with similar problems. The induk were local associations created to improve the quality of output and the production techniques of small industries; to standardize production; to introduce efficient forms of organization; to instil cooperation; and to organize joint and cooperative sales of finished products. The crafts that the induk were formed around included woodwork, ceramics, textiles, ironwork, and leather goods,

8 Djojohadikuumo (ed.), The Government's Program on Industries, 3.

9 Djojohadikusumo (ed.), The Government's Program on Industries, 9-1o. 
with production occurring in various places in Java and Madura. The problems that plagued the production of these crafts pointed to a lack of managerial capabilities. However, the Department of Industries' programme focused exclusively on quality improvement and techniques of production. As a result, the induk still had difficulty in finding markets, getting the best possible price for their products, and securing raw materials. Related to this was the lack of an organized distribution apparatus and rational business organization due to inadequate knowledge of the most elementary principles of business administration. ${ }^{10}$

There was a wider problem concerning public administration. As Sumitro explained:

Until recently, the internal conditions of administration at the department were more or less chaotic. Even documentation and filing were not well taken care of. Preliminary reports and surveys frequently went missing. Basic reports were scattered all through sections and subsections. There was no concentration of master files. There was a lack of an adequate number of trained administrative personnel to disseminate and to follow up on reports coming in from regional branches. Control by the Department of Industries and its extended services of induks have been inefficiently executed. A good deal of overlapping and cross wiring could be observed in the course of our research. One of the fundamental reasons was probably the frequent transfer of people who were in charge of the supervision and control of induks. There was also a lack of delineation of responsibilities. Sometimes there was confusion concerning the agency responsible for the implementation of the induks. Was it the central Department of Industries or was it the regional branch (inspector) of the Department of Industries?'11

The lack of entrepreneurial skill amongst the indigenous population was well known, due to them being, as Boeke put it, on the non-productive side of the colonial dual economy. ${ }^{12}$ Sumitro's efforts to increase entrepreneurial capabilities by implementing government policies such as the Benteng Programme were seen to be a failure. The government found that 90 per cent of

10 Djojohadikusumo (ed.), The Government's Program on Industries, 15-16.

11 Djojohadikusumo (ed.), The Government's Program on Industries, 16-19.

12 J.H. Boeke, Economics and Economic Policy of Dual Societies. As Exemplified by Indonesia (Haarlem: Tjeenk Willink \& Zoon, 1953), 36-51. 
the Indonesians receiving help lacked business experience and their businesses often became fronts for Chinese-Indonesian businessmen. ${ }^{13}$

The failure of the Benteng Programme was a major setback to the idea that the Indonesian government could instantly develop an indigenous, entrepreneurial class through the application of government policies. Sumitro reiterated:

Lack of equipment was not the most serious bottleneck. Equally serious, if not more so, was the lack of skills in general, and the critical conditions of public administration in particular [...] Immediate improvement of our public administration is a precondition for satisfactory implementation of future economic and financial policies. We refer not only to the government but also to government controlled or government sponsored enterprises, banks, credit agencies, etc. ${ }^{14}$

It pointed to the need for Indonesia to create not only a class of entrepreneurs but a whole range of administrative capabilities and administrative scaffolding for growth. This was why the introduction of the concept of business administration seemed to be the perfect answer to the lack of Indonesian entrepreneurial spirit:

We have experienced to our bitter disappointment, however, that capital equipment purchased resulted in actual capital loss just because no account was taken of the organizational preparation and skills required to turn capital expenditures into really productive results. I would consider for the next five years the problems of human investment to be equally, if not more important than capital investments. ${ }^{15}$

\section{From Dutch to American Concepts of Management}

The government's initial effort to grapple with administrative management was through the Committee to Investigate Ministerial Organizations (Panitya

13 For more on the Benteng Programme, consult Thomas Lindblad, Bridges to New Business. The Economic Decolonization of Indonesia (Leiden: KITLV Press, 2008), 125-47.

14 Quoted in Douglas Paauw, Financing Development. The Indonesian Case (Glencoe: The Free Press, 1959), 75.

15 Sumitro Djojohadikusumo, 'Budget and Its Implications', in Ekonomi dan Keuangan Indonesia, Vol. vi, January (1953), 10. 
Negara untuk Menjelidiki Organisasi Kementerian-kementerian, or Panok), set up in 1952. The committee was tasked with halting the expansion of organizations and civil servants and creating uniform ministerial structures. Headed by legal specialist Abdul Karim Pringgodigdo, the report was published in $1954 .{ }^{16}$ The committee found formal legal and organizational differences: there was a highly differentiated organizational structure, with overlapping and redundant functions. ${ }^{17}$ They proposed reordering and regrouping the current structure into several ministerial sub-organizations. There was hostility to the changes. A division that was 'demoted' to a section felt slighted. The integration of redundant offices made many people anxious about the security of their positions. The transfer of an office, section, or division from one ministry to another was met with hostility, as that meant a loss of workers and prestige. There were other problems, too. One critic from the LAN wrote:

Perhaps it was the result of the inaccurate calculation of the committee, perhaps it could also be the result of stress among the implementers, especially the legal specialists [...] Within Panok there were five jurists, one legal expert, and one candidate jurist, and as a result the plan was created in a 'rigid' fashion with no escape clauses. ${ }^{18}$

He blamed the problems of Panok on the lack of public administration specialists. The failure of the so-called 'legal specialist' from the perspective of this public administration specialist pointed to the need for a change of mindset regarding organization.

There was an almost fanatical need to pry Indonesian practices away from Dutch practices. Sumitro Djojohadisukumo, in an inaugural lecture at the School for Business and Public Management (Perguruan Tinggi Ketataniagaan dan Ketatapradjaan) on 14 January 1957, said: 'I should stress that the term "administration" must not be confused with the term "administrasi" which is

16 Bintoro Tjokroamidjojo, 'Perkembangan Ilmu Administrasi Negara di Indonesia', in M. Makagiansar and Widjojo Nitisastro, Research di Indonesia, 1945-1965, Vol. IV: Bidang Sosial, Ekonomi dan Kebudajaan (Jakarta: Departemen Urusan Research Nasional, 1965), $22-3$.

17 Mohammad Sidik Moeljono, 'Rantjangan Panok', in Pantjawarsa LAN (Jakarta: Lembaga Administrasi Negara, 1963), 86-7.

18 Moeljono, 'Rantjangan Panok', 90-1. 'Mungkin a.l. karena perhitungan2 Panok kurang sempurna, mungkin djuga karena Panok terdiri dari orang-orang praktek dengan titik berat ahli hukum [...] Dalam Panok terdapat 5 juris, 1 ahli hukum, 1 tjalon juris, maka rantjangan Panok tersusun setjara "rigid" (strak, kaku) tanpa escape clausules.' 
usually used in Indonesia as an extension of the Dutch usage of the word.19 This disinterest in the colonial heritage was supported by a compelling argument: the bureaucratic tradition of the colonial state was too complicated to be able to be implemented effectively. In Sumitro's words:

We have taken over from the colonial government a bureaucratic body that is in itself very difficult to understand. The bureaucracy used difficult and complicated working methods. This difficult bureaucratic body was, during the colonial period, run by people who were acclimatized to working within such structures. At present, the same bureaucratic system is being filled with new employees whose technical capabilities and experience are not in line with the needs of the system. The procedures used in the colonial bureaucratic system (which are still being used today) are, according to the experience of the writer, very hard to understand and control. Often people working within the environment of these bureaucracies have a hard time understanding the regulations. As a result, decisions are often based on whims (or often people decide not to make any decision at all $).{ }^{20}$

Such a legal approach was considered anathema to economic development and represented what Sumitro called the regulation economy, in which regulations grew haphazardly and in contradictory ways, thus reducing economic efficiency. ${ }^{21}$ During the colonial period, a legal education was often the only

19 Sumitro Djojohadikusumo, Management dan Mismanagement dalam Perusahaan dan Masjarakat (Jakarta: Pembangunan, 1957), 3. 'Hendaklah saja tekankan, bahwa kata "administration" djangan ditjampur-adukkan dengan "administrasi" dalam arti jang lazim masih dipakai di Indonesia sebagai kelangsungan rangka pengertian bahasa Belanda.'

20 Sumitro Djojohadikusumo, Bunga Rampai Ekonomi (Jakarta: Indira, 1951), 266. 'Kita telah mengambil over dari pemerintahan kolonial, suatu badan birokrasi jang pada dirinja sudah sangat sukar difahami. Birokrasi tersebut mempergunakan tjara bekerdja jang sulit dan gecompliceerd. Badan birokrasi jang serba sulit itu, dizaman colonial didjalankan oleh tenaga2 jang sudah biasa bekerdja dalam susunan demikian. Dalam keadaan sekarang, system birokrasi tersebut diisi oleh tenaga2 baru jang baik mengenai pengalaman maupun ketjakapan technis, tidak menerima didikan jang sepadan. Procedure jang dipakai dalam susunan birokrasi bekas kolonial (jang dilandjutkan hingga sekarang), memang menurut pengalaman pengarang sendiri, adalah sangat sukar dimengerti dan dikendalikan. Seringkali orang2 jang harus kerdja dalam lingkungan badan birokrasi ini, tidak mengerti sendiri peraturan2 jang berlaku. Akibatnja ialah, tindakan2 jang diambil mempunjai sifat jang tidak karuan (ataupun sama sekali tiada diambil tindakan dan/atau keputusan).'

Djojohadikusumo, Management dan Mismanagement, 5 . 
training given to candidate administrators at schools such as the MOsviA/ osvia, the Law School (Rechtshoogeschool) and the Public Administration College (Bestuursacademie). The feeling of ambivalence towards the Dutch influence grew as the transgenerational shift occurred. The older generation clung to Dutch methods and the policymakers in government continued to send civil servants to study in the Netherlands. The shift was pushed through by the newly educated and the receipt of American aid assistance. It can be argued that the shift from the 'legal' to the 'practical' approach involved a shift from Dutch to American ideas. ${ }^{22}$

After the war, the Dutch development of public administration started to have an impact in Indonesia, as Gerrit van Poelje's 1942 book Bestuurskunde (Public administration) was translated in 1953, the same year as the publication of A. M. Donner's Nederlandsch bestuursrecht (Dutch administrative law). The BPN published 'Administrative Requirements for Social and Economic Development' in August $1954 \cdot{ }^{23}$ Ernst Utrecht's Pengantar Hukum Administrasi Negara (Introduction to public administration law) was published in 1955, a year after the Panok committee had conducted their study and published their plans. According to the communist economist Carmel Budiardjo,

The experts in England and the United States in general say that political science is about the study of power in society. Power is analysed on the basis of its properties, principles, development, framework, and consequences. In comparison, experts from countries under German influence maintain that political science studies the state as a legal phenomenon, in terms of juridical-constitutional interpretation and administrative law. ${ }^{24}$

The Anglo-Saxon approach was to see the administration of the state as similar to the administration of the company. The main ideas of business administration, such as 'organization' and 'management', were imported and geared

22 There was a growing interest in economics and the other social sciences that had begun to rival law as a potential subject of study, for instance. Glassburner, 'High-Level Manpower for Economic Development', 18 o.

23 Bintoro Tjokroamidjojo, 'Perkembangan Ilmu Administrasi Negara di Indonesia', 27-8.

24 Ernst Utrecht, "Beberapa Tjatatan tentang "Public Administration” berhubungan dengan Pidato-pidato Prajudi dan Tjia Kok Tjiang', Padjadjaran, 1/2 (November 1958), 52. 'Para sardjana di Inggris dan Amerika Serikat umumnja mengatakan bahwa ilmu politik mempeladjari soal kekuasaan dalam masjarakat. Kekuasaan ini diperlihatkan sifatnja, asasnja, perkembangannja, rangka dan akibatnja. Sebaliknja ahli-ahli dari Negara jang terpengaruh oleh Djerman mempertahankan bahwa ilmu politik terutama mempeladjari "negara" sebagai gedjala hukum, tafsiran juridis UUD dan hukum administratief.' 
towards the practical and the pragmatic. The resultant system was supposed to be efficient and flexible, and geared towards problem-solving rather than merely the implementation of regulations and the law. Ernst Utrecht warned that such alacrity in accepting American ideas was dangerous and that 'there is nothing wrong with us directing our interest to the problem-solving system of progressive countries like the People's Republic of China'.25 One important development in this shift was the American-funded visit to Indonesia of two Cornell professors in the early 195os.

\section{Lichtfeld and Rankin's Visit}

In 1954, the Indonesian government invited Dr Edward H. Lichtfeld and Dr Alan C. Rankin, then respectively dean and assistant professor of Cornell's School of Business and Public Administration, to conduct a three-month survey of Indonesia's administrative problems. The two men met with important Indonesian leaders, including Vice President Mohammad Hatta; the head of the National Planning Bureau, Ir. Djuanda Kartawidjaja; ${ }^{26}$ and prominent intellectuals such as Dr Muhammad Yamin, Dr Sumitro Djojohadikusumo, and Dr Raden Supomo, president of the University of Indonesia. Lichtfeld and Rankin interviewed various Indonesians in top-, middle- and low-level positions in government.

The report they published pointed to a grave lack of knowledge of the basic concepts of public administration everywhere they went: government offices, hospitals, schools, and so forth. 'Generally speaking, we would say that the field of administrative science is largely unknown in contemporary Indonesia', Lichtfeld and Rankin concluded. ${ }^{27}$ They suggested the creation of universitybased, Indonesian administrative courses, as well as the establishment of libraries and the training of librarians. They encouraged the development of relevant literature in administration science, including the acquisition of foreign materials, the translation of standard materials, and the development of Indonesian-based literature. Dwight Waldo's The Study of Public Administration was published in Indonesian in $1955 .{ }^{28}$ There were only a couple of

25 Utrecht, 'Beberapa Tjatatan tentang "Public Administration”, 72.

26 'Ir.' is short for ingenieur (Dutch) or insinyur (Indonesian); it is the title used to refer to someone holding an engineer's degree in the Netherlands and Indonesia, among others.

27 Edward H. Lichtfeld and Alan C. Rankin, Training for Administration in Indonesia (Ithaca: Cornell University, 1954), 11.

28 It was translated by Slamet W. Atmosoedarmo and published in 1955 as Pengantar Studi Public Administration. The term 'public administration' was left in its English original, signalling the novelty of the entire discourse for the Indonesian intellectual public. 
hundred books available for the entire university system in Indonesia, many of which were imported and only relevant to Indonesia tangentially. Many universities did not have a library. The available books on Indonesia were confined mostly to those written in the Law Department and a few on the economy, with practically no supporting literature on political science and psychology. ${ }^{29}$

The next step was to develop university faculties in administrative science. The temporary importation of foreign teachers and the active training for a permanent, Indonesian faculty would be required. They suggested a programme of graduate work involving three years of study in residence and a fourth year in the field leading to a $\mathrm{PhD}$. They calculated that if only one person were to be trained each year for each of the ministries, provinces, regencies, and very large cities, then over two hundred graduates a year would be needed. Thus a four-year undergraduate training programme for one thousand students would be needed. In fact, it would need to be larger, considering the rate of attrition, which they calculated conservatively to be around 25 per cent. ${ }^{30}$

\section{$5 \quad$ Effect and Criticism of the Public Administration}

A committee was formed to follow up on the report. It was led by Vice President Mohammad Hatta, with Djuanda Kartawidjaja of the BPN, M. Hutasoit from the Ministry of Culture and Education, and Sumarman as members. The committee agreed on the development of a specifically Indonesian programme that would unite both public and business administration within a single educational centre. In 1956, the ICA created a public administration division in Jakarta, appointing Harry W. Marsh and John A. Ulinski as officers. The ICA programme focused on importing books on administration and sending Indonesians to study scientific administration abroad. ${ }^{31}$ The interest in public administration resulted in the swift expansion of state-sponsored institutional development pertaining to education and research, including, for instance, the creation of the Domestic Government Academy (Akademi Pemerintahan Dalam Negeri, or APDN) by the Ministry of the Interior in March 1956. Pupils at the APDN were taught the latest findings in public administration, to the detriment of administrative law. American public administration specialists

Dwight Waldo, The Administrative State. A Study of the Political Theory of American Public Administration (New York: Ronald Press Co., 1948).

29 Lichtfeld and Rankin, Training for Administration in Indonesia, 13-14.

30 Lichtfeld and Rankin, Training for Administration in Indonesia, 19-20.

31 Lichtfeld and Rankin, Training for Administration in Indonesia, 19-20. 
Garth C. Jones and Henry W. Bush taught at the school. ${ }^{32}$ Indonesia thus had cutting-edge specialists, books, and knowledge on this matter.

On 20 September 1956, Prajudi Atmosudirdjo gave the inaugural lecture on public administration at the Faculty of Administration at the private University Krisnadwipajana in Jakarta. In December of the same year, Tjia Kok Tjiang also opened a Faculty of Public Administration at the Universitas Indonesia in Makassar. Ernst Utrecht's criticism of these lectures accused both men of being dilettantes and intellectually dishonest. On Prajudi's lecture, he said: 'I've never encountered from the mouth of an Indonesian intellectual such a series of nonsense and lies, as has been spoken (in said lecture). ${ }^{33}$ Utrecht's main criticism was of the danger of overestimating the abilities of public administration and the consequent loss of interest in understanding the importance of administrative law (hukum tata-negara).

Public administration and scientific management had become modern mantras that promised the arrival of efficiency and order as if by magic. Utrecht called them mode-woorden and even toverwoorden, magical words. ${ }^{34}$ 'Has the result of public administration matched the enormous interest we have in it?', he asked, answering in the negative. ${ }^{35}$ A USAID report said in 1964: 'One of the current fetishes in most developing countries is the field of "management". Everyone seems to look on it as a panacea to all problems. ${ }^{36}$ American support for its expansion also meant that it not only conformed to the intellectual fashion of the day, but that authorities saw it as an opportunity to obtain the funds and aid that the US had made available.

American books were seldom contextualized for the Indonesian situation. ${ }^{37}$ The case studies compiled and used as the foundation for the contextualized Indonesian science of public and private management lacked a deep understanding of the 'ecology' of the power relationships and institutions that were needed. ${ }^{38}$ This lack of development in Indonesian political science made it

32 Tjokroamidjojo, 'Perkembangan Ilmu Administrasi Negara di Indonesia', 33-4.

33 Utrecht, "Beberapa Tjatatan tentang "Public Administration", 47. 'Belum pernah saja mendengar dari mulut seorang tjendikiawan bangsa Indonesia suatu rentetan omongkosong dan bohong, seperti tertera dalam kutipan diatas.'

34 Utrecht, 'Beberapa Tjatatan tentang "Public Administration", 69-70.

35 Utrecht, 'Beberapa Tjatatan tentang “Public Administration”, 68.

36 UsAid, Human Resource Development. Problems, Policies, Programs (Jakarta: UsAid, 1964), 11.

37 Often, the books were rehashed versions of American books with little effort to apply the knowledge to an Indonesian context or situation.

38 J. Rossall, Dale McKeen and Leon A. Mears, Indonesian Cases in Business Administration (Jakarta: LPEM, 1961); see also Everett Hawkins, Cases in Business Administration (Yogyakarta: Fakultas Ekonomi-UGM, 1964). The analysis of the cases was politically 
difficult to fully analyse the 'ecological' context of the manager. The problem was twofold. First, if such legal changes in the state system gave greater authority to managers, they required the redistribution of the power of the political elites in favour of their 'expert'-based elite, and this did not happen. Second, 'scientific management' was a 'magic word' for the political elite that was simultaneously supported by US aid, and this effectively blocked the need to deal with the 'real' problem, which was a political one.

\section{The Development of Business Management}

Business administration grew rapidly in the 1950s and exhibited the same shift from the Dutch/Continental style to an American/Anglo-Saxon one. Barli Halim divided the period into three: $1945^{-1957}$ as a Continental period, $195^{8-1959}$ as an Anglo-Saxon one, and 1960-1965 as a period of business management science based on Indonesian socialism. ${ }^{39}$ Although he saw the Americanization as a brief and almost insignificant one-year period of development, it would be foolish to underestimate the strength of its message and ideology. Reading through works on business administration from the 1960s easily shows how replete ideas of scientific management were within the pages of supposedly socialist Indonesian tracts on management.

The 'Indonesianization' of business administration lagged behind public administration for several reasons. First, business administration was a lot less politically sensitive than public administration. Second, Dutch perspectives continued to pervade business administration as a result of the continued presence of the Dutch in Indonesian universities. Third, the continuing and large presence of Dutch-owned enterprises meant that there was a likelihood of Indonesian graduates entering into employment with these enterprises and thus the relevance of a Dutch perspective on business administration continued. All of this ended with the nationalization of Dutch-owned enterprises and the forced repatriation of Dutch citizens in 1957.

There were basically three main paths to obtaining a business management education in the country: university courses, corporate business courses, and state-sponsored courses. Business administration was not taught in higher-education institutions during the colonial period. The only faculty

detached and focused on a purely economic approach, instead of understanding the wider societal and political implications of inefficiency.

39 Barli Halim, 'Ilmu Ekonomi Perusahaan', in M. Makagiansar and Widjojo Nitisastro (ed.), Research di Indonesia, 211. 
that offered some economics teaching was the Law Faculty. Only fifteen Indonesian economists were available on independence; they had graduated from Dutch universities, mostly the Erasmus University in Rotterdam. After independence, three universities developed relatively strong economics faculties: the University of Indonesia, Gadjah Mada University, and the Protestant Nommensen University in Medan. A college of business management was set up in the early 1950s by Dutch commercial organizations and chambers of commerce, representing a private-sector response to the need for commercial managers. ${ }^{40}$

The Dutch approach to business economics focused on the study of the firm. This liberal approach contrasted with the study of the state, that is, its role in economic development, in the nascent science of developmental economics. The study of business management was divided into four sciences: cost theory (ilmu biaya), expenditure theory (ilmu belandja), external organization theory, and internal organization theory. The books were also in Dutch - for example, Jan C. Rietveld's Inleidend leerboek der bedrijfseconomie (Introductory Textbook of Business Economics), B. van der Meer's Schets der bedriffseconomie (Sketch of business economics), and P. J. Potgieter's Inleiding tot de bedrijfseconomie (Introduction to business economics). ${ }^{41}$

In 1955, the FEU I discussed the possibility of linking up with an American university to support the improvement of the Indonesian teaching staff. Since the early 195os, Sumitro had succeeded in recruiting Dutch teachers through his connections with the Rotterdam School of Economics. ${ }^{42}$ In 1956, an agreement was signed with the University of California at Berkeley for education that was to be funded by the Ford Foundation. As well as sending young Indonesian lecturers to pursue post-graduate studies there, UC Berkeley would also send professors to teach at UI. In 1957, six UI staff members were sent to California while Berkeley sent three of their staff members to the institute. In 1955, Universitas Gadjah Mada had taken the subject of economics out of the Law, Economics and Social Science Faculty and created a standalone Economics Faculty, appointing lecturers Dr J. B. Stock; Prof Stanislaw Swianiewicz, a Polish economist; and Prof C. de Heer, ${ }^{43}$ the former professor of business enterprise at Makassar. ${ }^{44}$ In 1957, UGM signed an agreement with the

$40 \quad$ Antara, 29 November 1953.

41 Halim, 'Ilmu Ekonomi Perusahaan', 213-14.

42 Thee Kian Wie, 'Economics', in Koentjaraningrat (ed.), The Social Sciences in Indonesia (Jakarta: LIPI, 1979), 229.

43 Sardjito, Laporan Tahunan Universitas Gadjah Mada 1955/1956, 4.

44 A. N. J. de Hollander, The Social Sciences in Indonesia (Paris: UnEsCo, 1951). 
Ford Foundation and Wisconsin University, which led to the arrival of eight foreign lecturers, six of which came from Wisconsin University, including Everett Hawkins. ${ }^{45}$

The first change that they made was to replace the theories that were being taught in classes. The theories of the American Frederick Taylor and the French Henri Fayol now started to make their appearance. Fayol divided business administration into six parts: management, production, marketing, financing, accountancy, and personnel. American textbooks appeared in Indonesia for the first time: Prentice Hall, McGraw and Hill, and Macmillan, among others, provided more pragmatic books, designed for the uninitiated. ${ }^{46} \mathrm{~A}$ shift was also observable in the method of teaching. The introduction of discussion groups and seminars was seen as a refreshing change from the lecture formats of the Dutch professors. The introduction of Indonesian case study methods was empirical and contextual. The business administration curriculum was an import from the USA. ${ }^{47}$ The curriculum consisted of an introduction to Taylorist scientific management and a collection of case studies of companies and their problems. Leon A. Mears and Rossall J. Johnson were among the first to collect business case studies in Indonesia. ${ }^{48}$

The rise of interest in business administration was portrayed succinctly in the Caldwell and Timms report. The report was published on 1 November 1958, having been commissioned by the BPN, and was the result of a survey of Indonesia by Linton K. Caldwell, professor of government and director of public service training, and Howard L. Timms, professor of business management, from Indiana University, ${ }^{49}$ between the months of July and August of the same year. They interviewed around $300-350$ leaders in public administration, business management, and education, half of them in Jakarta and the rest in other cities including Bogor, Bandung, Pekalongan, Semarang, Yogyakarta, Surabaya, Malang, Medan, and Palembang. Because of the short, two-month stay of the consultants and their general prior ignorance of Indonesia, the report

45 Sardjito, Laporan Tahunan Universitas Gadjah Mada 1955/1956, 13-14.

46 Halim, 'Ilmu Ekonomi Perusahaan', 216.

47 Caldwell and Timms, Developing the Managerial Resources of Indonesia, 40-1.

48 Johnson, McKeen and Mears, Indonesian Cases in Business Administration.

49 J. Panglaykim (1968). Managerial Development: An Indonesian Experience, Australian Journal of Public Administration, $27(1), 66$. 
functioned more as an instrument through which Indonesians working in the field could express their general ideas. ${ }^{50}$

The report was important exactly because it recorded the sentiments of general Indonesian managers at the beginning of the Guided Democracy. There was a degree of apprehension amongst those interviewed that the gradual retirement of most Dutch-trained administrators would reduce the efficacy and efficiency of the administration. ${ }^{51}$

The report highlighted several issues that needed to be addressed to develop business administration. As an immediate goal, it called for the creation of a management development programme, modelled after the Advanced Management Programme of the Far East in the Philippines. This was an extension of the Advanced Management Program set up by the Harvard School of Business Management. It also called for the establishment of evening courses in business administration at business and government centres throughout Indonesia and within the Indonesian universities. As a long-term goal, it emphasized the need to speed upthe graduation of students by supporting the doctorandus programme in business administration at the University of Indonesia, which was at the time the most advanced programme in business administration in the country. Lastly, it called for the development of a first-rate institution of higher education, similar to the Harvard School of Business Management. This, it argued, should be located within the FEUI. ${ }^{52}$

As a follow-up to the Caldwell and Timms report, a committee headed by the economists Subroto, Mohammad Sadli, Panglaykim, and Arifin Abdulrachman was created. Many of the experts were from the FEUI. The focus on business management resulted in the formation of a series of managerial courses that were meant to upgrade the capabilities of business managers, especially those at state-owned companies. With the help of the Ford Foundation and the University of California, a Management Development (Pembangunan Ketatalaksanaan) course was set up.

In 1957, the law professor Djokosoetono took on the role of acting dean of the Economics Faculty of the Universitas Indonesia after Sumitro Djojohadikusumo joined the PRRI rebellion in Sumatra. As part of the shift to the Guided Democracy, the curriculum of the faculty was also revamped. Djokosoetono felt that the curriculum should be geared towards the specific needs of the

$5^{\circ}$ Linton K. Caldwell and Howard L. Timms, Developing the Managerial Resources of Indonesia. A Report to the Biro Perantjang Negara (Bloomington: Indiana University, 1958),

8. ANRI, Mohammad Bondan, inv. no. 699.

$5^{1}$ Caldwell and Timms, Developing the Managerial Resources of Indonesia, 9.

$5^{2}$ Caldwell and Timms, Developing the Managerial Resources of Indonesia, 48-50. 
developing country. 'Luxury' and 'liberal' courses were eliminated, and the dabbling in 'abstract analyses' was discontinued. ${ }^{53}$ The Dutch curriculum had included a large proportion of law education, including courses on private law, fiscal law, Islamic law, and commercial law at the undergraduate level. After the changes, many of the economics courses focused less on the different aspect of law. ${ }^{54}$

The shift towards an American curriculum, alongside the introduction of American-influenced sciences such as public and business administration, was significant and widespread. Before 1955, economics was taught within a single Social Science Faculty and was heavily based on the Dutch curriculum. All the books and articles used in the courses were Dutch in origin. ${ }^{55}$ The overall result of the changes led to a more pragmatic focus, that is, a heavier emphasis on applied economics. The economics courses offered three fields of specialization: general economics, business economics, and accountancy. In 1964, governmental economics was introduced. These changes occurred throughout the university system.

Another important reason for the Americanization of the curriculum lay in a shift in language ability. Thee Kian Wie argued that since the mid 195os, there had been an influx of students with little ability to command the Dutch language because their primary education had started after the Japanese invasion in 1942. This change in language proficiency necessitated the move towards English-based reading materials. ${ }^{56}$

In a report submitted by the labour division of USAID in February 1964, the root of the problem with implementing Indonesian management science was spelled out. The report outlined several issues:

First, the approach has been substantially one of taking Western management concepts and methods and attempting to overlay them on a culture and economy not yet attuned to them. The result is that the trainees can, at the conclusion of their course, glibly repeat the management jargon, but the basic cultural barriers have not been broken through. Processes of thinking and acting have not fundamentally changed. Second, the courses tend to be academic and abstract; there is little emphasis on or use of the case methods or the problem-solving technique. As a result, there Dwi-Dasawarsa dan Reuni Alumni Ke II, Jakarta, 1970 (Jakarta: FEUI, 1970).

54 Thee, 'Economics', 230-4.

55 Thee, 'Economics', 230-4.

56 Thee, 'Economics', 231-2. 
is no effective transition from principle to practice. Third, the teaching process consists almost entirely of 'lectures', which, in this case, usually consist of transferring the notes from the book of the lecturer to that of the student without necessarily passing through the minds of either. ${ }^{57}$

The report laid out two suggestions for the development of public administration. First, an approach geared towards the social mores of the Indonesians rather than an attempt to transplant Western management ideology was necessary. Second, the introduction of an in-depth programme, which would attend to the specific skills and practices of management and supervision and would not merely focus on the academic side of things. ${ }^{58}$

Garth N. Jones saw that the problem with Indonesian public administration was its decontextualized character: 'Unfortunately, there is a dearth of scholarly studies concerning the social milieu of Indonesia. Public administrators even if they understand the importance of the relationship of social science to their work, must operate almost in a void of knowledge about their social setting.59 As a result, in the early 196os, he advocated that any technical assistance programme must be focused on a scholarly study of the social milieu, governmental structures, and processes, meaning that a considerable effort would have to be made to obtain solid and basic information on the Indonesian government and society. ${ }^{60}$ He summed this up by saying, 'Fundamentally, the management process must be brought down out of the sky and back to earth. ${ }^{61}$ It was stressed that the pouring of capital investment into an economy or a society not yet ready to expand its productive capacity represented a waste of money.

\section{8}

\section{Production of a Managerial Class}

The expansion of schooling in public and business management was proof of the Indonesian government's commitment to expanding the nation's managerial class. The less than satisfying result of the PUTABA scheme may have been one of the reasons, but it was always expected that the Indonesian state and

57 USAID, Human Resource Development, 8.

$5^{8}$ USAID, Human Resource Development, 11.

59 Garth N. Jones, 'Some Critical Areas concerning Technical Assistance in Public Administration in Indonesia', Bulletin Lembaga Administrasi Negara, 1 (1961), 10-11.

$60 \quad$ Jones, 'Some Critical Areas', 13.

61 USAID, Human Resource Development, 11. 
society would be managed by Indonesians. For instance, the Eight-Year Development Plan published in the early 196os stated that each state university was to be equipped with a Faculty of Public Administration. ${ }^{62}$

There was a strong connection between civilian and military managers. For instance, the Manager magazine produced special editions in which military management was discussed. Generals including Nasution, Ibrahim Adjie, and Ahmad Yani graced these editions with their opinions, including an article by Nasution on the Paran and one by Ibrahim Adjie on the Civic Action programme. ${ }^{63}$ Aside from the military elites, most other contributors came from the civilian expert elite, including First Minister Djuanda. A coterie of military and civilian experts, most with ties to or sympathy for the PSI, represented the core managerial class of the country. This was the same group of people that would eventually come to power under the banner of the New Order.

The significant feelings of inadequacy that are apparent in the grumblings about the 'cultural' weaknesses of the Indonesian managers and the almost triumphant exclamation of the managerial revolution by those same managers offers an interesting juxtaposition. In magazines such as Fortuna, Manager, and Perusahaan Negara, references to managers as the future leaders of the country abound. The confinement of managerial production to the social sciences was a unique and modern perspective. It is now prevalent in the United States to leave behind the old tradition that assumes potential managers require them to be educated in engineering. The large industries in today's America, with their various kinds of societal activities, are a modern social group'. What was desirable in a person was their flexibility. Many American companies in fact claimed that humanities and social science students were preferred over more technical types. ${ }^{64}$

On the other side of management, the expansion of the doctorandus degree in business management continued apace and, in fact, the intake of business management students climbed rapidly after the takeover of Dutch-owned businesses in Indonesia. The table below shows the number of FEUI graduates during the period $195^{2-1963}$ and illustrates that business management trailed behind general economics in terms of numbers of graduates. Yet, even more significant was the expansion of the student intake in business management

62 Rantjangan Dasar UU Pembangunan Nasional-Semesta Berentjana Delapan Tahun: 19611969. Bidang Mental/Ruhani dan Penelitian, Buku Ke III, Djilik Ke vi: Pola Pendjelasan Bidang Pendidikan Tenaga Pembangunan (Jakarta: Dewan Perentjanaan Negara, 196o), 1751.

63 Nasution, 'Kata Sambutan', 4-9; Adjie, 'TNI dan "Civic Mission", 10-15.

64 'Apakah Anda Laksanawan Type Baru?', Fortuna, 1/11 (February 1961), 744-8. 
TABLE 11 Graduates in the three departments of the Faculty of Economics at the University of Indonesia

\begin{tabular}{lrcr}
\hline & Economics & Business management & Accountancy \\
\hline $195^{2-1953}$ & 0 & 2 & 2 \\
$1953^{-1954}$ & 0 & 1 & 1 \\
$1954-1955$ & 4 & 1 & 5 \\
$1955^{-1956}$ & 14 & 9 & 23 \\
$1956-1967$ & 17 & 9 & 30 \\
$1957-1958$ & 11 & 9 & 21 \\
$1958-1959$ & 45 & 22 & 69 \\
$1959-1960$ & 146 & 37 & 203 \\
$1960-1961$ & 76 & 34 & 138 \\
$1961-1962$ & 58 & 36 & 103 \\
$1962-1963$ & 58 & 50 & 128 \\
Total & 426 & 210 & 723 \\
\hline
\end{tabular}

SOURCE: TAKEN FROM J. PANGLAYKIM, 'SOME NOTES ON THE DEVELOPMENT OF ECONOMIC AND BUSINESS ADMINISTRATION EDUCATION IN INDONESIA', DE ECONOMIST, 113/ 4 (1965), 281

science. The most significant rises occurred in 1959-1960, when 146 economics majors graduated, and in 1960-1961, when thirty-seven business management majors graduated.

The FEUI produced its first business administration graduates as early as 1952. Yet, until 1957, enrolment in the subject remained fairly limited. Enrolment numbers increased from 1958. However, these figures were dwarfed by the expansion of the Economics Department, which enrolled more than one hundred students in 1959 in anticipation of the Guided Economy. By 1963, a total of 210 business administrators had been educated by FEUI, about half the number of the 429 graduates in economics. Yet, if we look at enrolment for 1963-1964, there were around 101 first-year and 28o second-year undergraduate students in business administration at FEUI, in comparison to just 26 first-year and 104 second-year students in general economics. The unmistakable trend was of an increasing interest in business administration in comparison to general economics as the 196 os wore on. ${ }^{65}$

65 Panglaykim, 'Development of Economic and Business Administration Education', 277-91. 


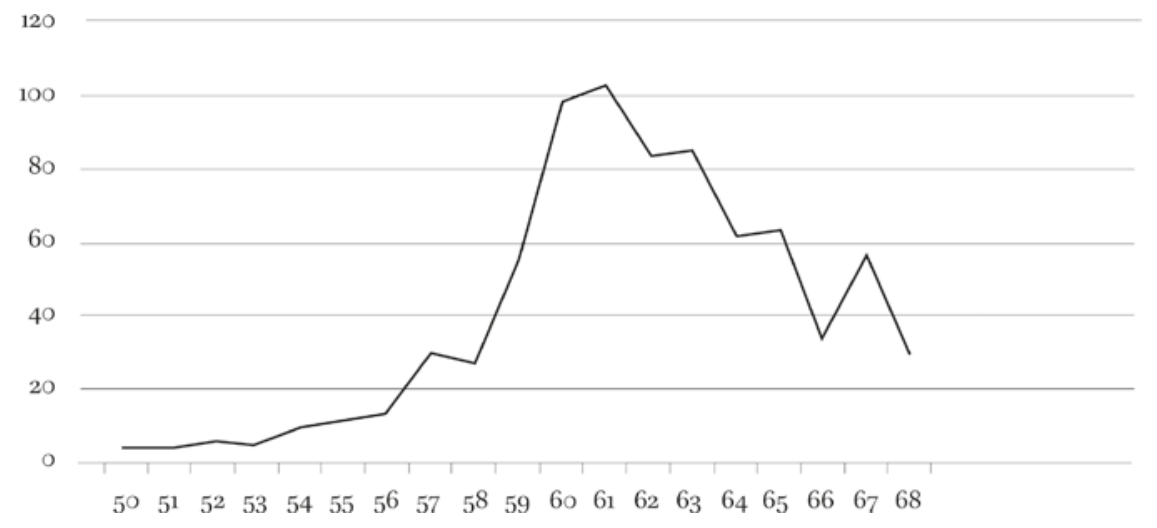

FIGURE 5 Production of books and articles on managerial science between 1950 and 1968, with a peak in 1961

SOURCE: TAKEN FROM THE LIANG GIE, BIBLIOGRAFI ILMU ADMINISTRASI PENERBIT KARYA: YOGYAKARTA, 1970, 184-5

The interest in public and business management thus peaked during the early part of the Guided Democracy, between the years 1957 and 1962. This expansion could be seen in both the rising interest in business management courses and the increasing production of books, especially on public administration. In a survey of the production of books on various subjects labelled as administration, The Liang Gie found a peak in $1960-1961,{ }^{66}$ at the time when Law 19/1960 was passed, which effectively transferred the coordination of the entire economy, including the private economy, into the hands of the government. The number of articles produced reached a peak in 196o with eighty-six articles and in 1961 with eighty-nine articles, as the chart below indicates. Of the 289 published books on administration, ninety-one, or a third of the total, were translations. ${ }^{67}$ After this year, the production of both articles and books fell. This was then followed by the closure of the journal Madjalah Manager in 1965 .

The Executive Development Programme (Program Pembangunan Ketatalaksanaan), which was supported by the Ford Foundation, was launched at FEUI in 1960 and taught a curriculum that was in line with the one at the LAN, one mostly associated with the problems of authority, decisionmaking, and leadership. ${ }^{68}$ At Universitas Gadjah Mada, the success of the

66 The Liang Gie, Bibliografi Ilmu Administrasi (Yogyakarta: Penerbit Karya, 1970), 184-5.

67 The, Bibliografi Ilmu Administrasi, 183 and 209-10.

68 Aminin Honggodjojo, 'Curricula Implications in Management Education for Present and Future Needs', in Yip Yat Hoong (ed.), Role of Universities in Management Education 
Administration Development Center (Balai Pembinaan Administrasi, BPA), peaked with its involvement in the Congress of the Science of Public and Business Administration held in 1961 in collaboration with the LAN. ${ }^{69}$ The LAN produced over twenty-five publications between 1958 and $1963 .{ }^{70} \mathrm{~A}$ series of managerial courses were introduced by a variety of organizations. The Ministry of Industry, for instance, set up a Academy of Industrial Management (Akademi Pemimpin Perusahaan) in 1958, copying the principles and curriculum of the Massachusetts Institute of Technology's School of Industrial Technology. ${ }^{71}$

Within the field of agricultural estates, the nationalization of Dutch-owned companies resulted in the Indonesianization of 2,300 managerial positions across four hundred estates. ${ }^{72}$ The creation of professional, that is, universitytrained, managers could not keep up with this expansion. Atmosudirdjo reckoned that if Universitas Gadjah Mada produced approximately one hundred graduates, Padjadjaran thirty graduates, LAN fifty graduates and Hassanudin twenty graduates, this would only total two hundred managers, which was not enough. ${ }^{73}$ In its eight-year history, by 1959 the FEUI had produced just sixty economists: fifty-five business administrators and five accountants. ${ }^{74}$ The limited ability of the education system to produce professional managers meant that a large percentage of managerial personnel came from other parts of society. Panglaykim pared these down to six categories, including civil servants, military personnel, and university graduates. ${ }^{75}$ The majority of managers had studied at general schools during the colonial period. Some were former teachers, civil servants, or army personnel. ${ }^{76}$

for National Development in Southeast Asia (Singapore: Regional Institute of Higher Education and Development, 1972), 213-25.

69 The, Bibliografi Ilmu Administrasi, 188.

70 Imam Buchari, Buku Peringatan Pantjawarsa Lembaga Administrasi Negara, 1958-1963 (Jakarta: Lembaga Administrasi Negara, 1963), 40-1.

71 Program Akademi Pemimpin Perusahaan, 1958-1959 (Jakarta: Kementerian Perindustrian, n.a.), 3-15.

72 Everett D. Hawkins, 'Indonesia', in Walter Galenson (ed.), Labor in Developing Economies (Berkeley: University of California Press, 1962), 117.

73 Atmosudirdjo, 'Masalah Pendidikan Ilmu Administrasi', 34.

74 Mohammad Sadli, The Structural and Operational Aspects of Public (Especially Industrial) Enterprises in Indonesia (Jakarta: n.n., 1959), 249.

75 Panglaykim, State Trading Corporations in Indonesia. First Year's Performance, 1961 (Jakarta: Jajasan Badan Penerbit Fe ui, 1965), 7-8.

76 Achmad Sanusi, Manager: Insentif dan Motif Putusannja. Satu Perbandingan Umum pada Perusahaan2 di Uni Sovjet, Amerika dan Indonesia (Bandung: Universitas Bandung, 1964), 62-3. 
Who was the Indonesian manager? Achmad Sanusi put it this way:

Sometimes he is depicted as an ideologist, a carrier of the people's wishes, and a father faithful to his children. He does not have a university education, but has had plenty of experience and knows deeply the bitter laws of life. At other times, he is shown as a young person, a student, who is trying and experimenting, behaving in a formalist fashion, still lacking skill in translating policy from theory and not clever enough to play the games according to the real rules. Sometimes, the manager takes on the image of a leader of society, who is constantly managing his relationship with government leaders and heads of departments, who cooperates with and for businessmen, lending them his name and service. ${ }^{77}$

Jamie Mackie's survey of agricultural estate companies in 1960-1961 showed the extent to which the rise of the new managerial elite had resulted in the formation of new regional power structures:

Relatively powerless in central politics, the new managers appear to be an influential group in the daerahs (districts), particularly in those where there are close bonds of interest and affinity between them and the existing regional authorities, pamongpradja and Army officers. Thus, the divorce between political power and responsibility for production, which characterized the years $195^{\circ}-57$, has been remedied (in a uniquely Indonesian fashion) at the regional level. ${ }^{78}$

77 Sanusi, Manager: Insentif dan Motif Putusannja, 67. 'Kadang2 ia tergambarlah sebagai seorang karyawan ideologist, pengemban amanat penderitaan rakjat, dan sebagai bapak jang setia kepada anaknja. Ia tak berpendidikan universiter, tapi telah tjukup banjak makan garam, dan tahu betul kenjataan hukum2 hidup jang pahit-getir sekalipun. Lain kali manager Indonesia tergambar sebagai tokoh muda, sardjana, jang sedang membuat eksperimen2, masih banjak formalism, belum handig lagi membuat satu policy dari satu teori, dan belum lagi pandai main "the games according to the real ground-rules". Kadang2 manager kita tergambar lagi sebagai symbol tokoh masjarakat, jang pernah dan terus memperhatikan banjak relasinja dengan pimpinan pemerintahan, djawatan2, jang bekerdja-sama dengan, atau untuk, pengusaha2 jang memindjam nama dan djasa2nja itu. Betapapun sifat2 itu jang lebih sesuai, manager di Indonesia pun dipandang umum sebagai satu golongan elite jang kedudukan ekonomisnja lebih tinggi, dan hidupnja jauh lebih mewah daripada rata2 penduduk biasa, bahkan djuga dapat mempengaruhi djalan pelaksanaan politik pemerintah atau djawatan2.'

78 J. A. C. Mackie, 'Indonesia's Government Estate's and Their Masters', Pacific Affairs, 34/4 (Winter 1961-1962), 339-40. 
This 'federalization' of the regions under military rule resulted in a significant restructuring of the state. As Daniel Lev phrases it: 'Already identified with their provinces, army commands hyperactively and over-optimistically undertook to fulfil local demands for the economic development which civilian government had been unable to accomplish. ${ }^{19}$ The development of a militarycum-expert planning structure, within what was to become the Bappenas planning structure, provided the solution to the problem of decentralization.

\section{$9 \quad$ Public Administration, the Welfare State and Guided Democracy}

The pro-Sukarnoist legal specialist and PNI member Ernst Utrecht viewed the move to the Guided Democracy as a shift from the Continental Rechtsstaat to the Anglo-Saxon welfare state or Wohlfahrtstaat. ${ }^{80}$ The German Rechtsstaat attempted to impose a legal order in which all government decisions could be regulated within the law; however, problems appeared when the state began to expand its function as part of the development of social services and as a purveyor of public goods. ${ }^{81}$ 'This narrow view strait-jacketed the government's activity within legal boundaries. As a result, when government activity was expanded because of the acceptance of the Wolhfahrtstaat, a 'web of administrative prescriptions' (net van administratieve voorschiften) that was increasingly complicated and in contradiction with itself was created. This was because of the wish that nothing be left to its own devices and that positive legal supervision be maintained. As a result, there appeared a bureaucracy that preferred to obstruct instead of support the government's activity in promoting general welfare and individual interests!'82 Quoting Yugoslavian legal specialist Eugen

79 Lev, The Transition to Guided Democracy, 63.

$80 \quad$ He hated the PSI and called it the party of champagne socialists (salonsocialist). See Eileen Utrecht, Twee zijden van een waterscheiding. Herrineringen aan Indonesië voor en na de onafhankelijkheid (Amsterdam: Sua, 1991), 87-9o, 138 and 152-62.

81 For more on the liberal character of the Rechtsstaat, see Rachel S. Turner, Neo-Liberal Ideology. History, Concepts and Policies (Edinburgh University Press, Edinburgh, 2008), $27-31$.

82 Utrecht, 'Beberapa Tjatatan tentang "Public Administration"', 62. 'Pendapat sempit ini hendak mengikat aktivitet pemerintah pada hukum. Akibatnja: ketika kemudian aktivitet pemerintah sangat diperluas karena diterimanja 'Wohlfahrtstaat', maka dilahirkan suatu 'net van administratieve voorschiften' luas jang sangat berbelit2 dan makin luas makin bertentangan (!), sebab keinginan supaja tiada sesuatupun jang dilepaskan dari pengawasan hukum positif tetap dipertahankan. Dengan demikian dilahirkan suatu birokrasi jang lebih menghalangi daripada memadjukan aktivitet pemerintah guna kepentingan umum maupun kepentingan individu sendiri!. 
Pusic, Utrecht wrote that 'administrative inefficiency, caused by legal guarantees, can finally reduce these guarantees to nil'. ${ }^{83}$

Sukarno, in a speech to the Indonesian Master of Law Association (Perhimpunan Sardjana Hukum Indonesia, Persahi) in 1961, said this of legalmindedness: 'Wilhelm Liebknecht has said - in Dutch - "you can't make revolutions with lawyers". ${ }^{84}$ What Liebknecht said was that most legal specialists, jurists, are very legalistic; they cling to the prevailing laws so strongly that if they were to be asked to join the revolution, which requires throwing away the current situation [...] these legalistic jurists, would find it very difficult to do so.'85 Sukarno equated legalistic thinking with being almost contrarevolutionary. In 1958, Sukarno established the Institute for the Development of National Law (Lembaga Pembinaan Hukum Nasional, LPHN), whose goal was to change the colonial roots of Indonesian law. ${ }^{86}$ In 196o, Sukarno gave ministerial status to the head of the Supreme Court (Kejaksaan Agung), thus suspending Indonesia's law-based state. ${ }^{87}$

During the inaugural address of the LAN, its head, Prajudi Atmosudirdjo, stated:

The formation of this LAN by the government signals the wish to speed up the changes in the spirit (djiwa) of our civil servant, who is currently a laughing stock of society. This is the change from a civil servant who

83 Utrecht, 'Beberapa Tjatatan tentang "Public Administration", 62.

84 'Met juristen kun je geen revolutie maken.'

85 Sukarno, Sosialisme dalam Kepribadian Indonesia. Pidato Presiden Sukarno pada Pembukaan Kongress Persahi di Jogjakarta, 26 Nopember 1961 (Jakarta: Departemen Penerangan, 1961), 4. 'Wilhelm Liebknecht telah berkata - salinannja dalam bahasa Belanda - "Met juristen kun je geen revolutie maken." Jang dimaksudkan oleh Liebknecht ialah bahwa ahli hukum, juristen, kebanjakan - demikianlah maksud Liebknecht - sangat legalistis, sangat memegang kepada hukum-hukum jang "prevaleren", sangat memegang kepada hukum-hukum jang ada, sehingga djikalau diadjak ber-revolusi - revolusi jang berarti melemparkan hukum jang ada, "a revolution rejects yesterday" kata seorang pemimpin revolusi jang lain, "a revolution rejects yesterday" - sehingga djikalau jurist-jurist jang legalistis ini diadjak ber-revolusi, katanja, amat sulitlah hal jang demikian itu.'

86 Keputusan Presiden Republik Indonesia No. 107 tahun 1958 tentang Lembaga Pembinaan Hukum Nasional (LPHN), ANRI, Jakarta, Mohammad Yamin, inv. no. 36o. The LPHN was composed of lawyers and other elements of society in order to create a legal system that was not merely based on a legal approach, but also able to accommodate other elements, at least this was the case stated by the minister of education and culture to the ministerial board in charge of creating the body. ANRI, Jakarta, Kabinet Perdana Menteri Republik Indonesia, inv. no. 1651.

87 A. M. Reksohadiprodjo, 'The Relations of Law and Economic Development. With Special Reference to Indonesia', MA thesis, Institute of Social Studies, The Hague, 1969, 33. 
'merely follows the rules' to a new Indonesian civil servant, one who has an entrepreneurial spirit which embodies the spirit of the 'managers of the state' or 'public managers', is full of personal initiative, and has a dynamic mindset in their efforts to increase their productivity and the national capital productivity in order to achieve the highest level of welfare for the people and the state, in as little time as possible. ${ }^{88}$

Even more significantly, the change in the spirit of the civil service was part of the underlying spirit of the Guided Democracy and that of the New Order state itself:

[T] he duty of this organization is to implement a government decision that is revolutionary in character. The decision of the government to create the LAN shows that the government is serious about creating a 'public administration' in Indonesia and represents an important caesura in the history of our government. With this decision, we leave behind the lawbased state' doctrine that we have inherited from the Dutch, and, without forgetting the law, we are on our way to becoming an 'administrative state', which is the most modern governmental idea, whereby the state is seen to form a sort of corporation (ondernemingsvorm). In comparison, the law-based state saw the state as merely a juridical-formal body. In a law-based state the main purpose of the government is to keep 'peace and order', while in an administrative state, the government actively conducts efforts to increase the welfare of the people and the state. In other words, with this government decision, we decidedly move from a 'legal state' towards an 'administrative state on a legal basis'. ${ }^{89}$

88 Pantjawarsa Lembaga Administrasi Negara (Jakarta: Lembaga Administrasi Negara, 1963), 10. 'Dengan mendirikannja Lembaga Administrasi Negara ini Pemerintah ingin mempertjepat proses perubahan djiwa pegawai2 negeri kita, jang pada masa ini masih selalu mendjadi edjekan masjarakat, jaitu perubahan dari pegawai negeri jang "hanja mendjalankan peraturan" sadja ke pegawai negeri Indonesia Baru, jang mempunjai entrepreneurship dan leadership, jang berdjiwa sebagai "managers of the state" atau "public managers" jang penuh inisiatif sendiri serta berdjiwa dinamis dan jang selalu berusaha untuk mempertinggi produktivitet kerdja, produktivitet mode nasional dan sebagainja, guna mentjapai kemakmuran Bangsa dan Negara jang se-tinggi2nja dalam waktu jang sesingkat2nja.'

89 Pantjawarsa Lembaga Administrasi Negara, 10. '[T] ugas Lembaga ini merupakan pelaksanaan dari suatu Keputusan Pemerintah jang bersifat revolusioner. Keputusan Pemerintah untuk mendirikan Lembaga Administrasi Negara jang berarti, bahwa Pemerintah setjara tegas hendak membangun "Public Administration" in Indonesia, adalah suatu titikperubahan pokok didalam sedjarah kenegaraan kita. Dengan keputusan tersebut kita 
There was thus a deep contradiction between the rise of the welfare state or, in Atmosudirdjo's words, the administrative state, and the traditional and 'liberal' forms of political democracy. In fact, the shift towards an administrative state was seen as leaving behind the trias politica and the separation of powers that had been the prime model of Western democracy since the French and American revolutions, and which had been reflected in the $195^{\circ}$ Indonesian 'liberal' constitution. The 'liberal' trias politica state was thus considered a night-watch state, which focused on the application of the law. In fact, Montesquieu's idea was based on the aim of denying the possibility of state tyranny and ensuring the liberty of the individual citizen. Thus, individual liberty was traded for the completion of revolution and development.

This constitutional reordering highlights several ideas related to the Guided Democracy state. The root of the failure of 195os' development was pointed out, quite correctly, as being a problem of planning and coordination. Sukarno attributed this to the inherent chaos that liberalism had induced. The fact that seven governments had existed between $195^{\circ}$ and 1957 certainly strengthened this accusation. According to Sukarno, the only way to solve this problem was to complete the Indonesian revolution. There were several obstacles to be overcome, if this were to be accomplished. First, Indonesia needed to eliminate the dualism between the 'government' and the 'revolutionary leaders' that had coloured governance in the 195os. Sukarno pointed out that, as a result of the compromise made in $195^{\circ}$ at the Round Table Conference and under the rule of the social democrats, "[o]ur earth became fertile for the growth of all types of conventional, conservative, reactionary, and contra-revolutionary and liberal ideas. ${ }^{90}$

These 'contra-revolutionary reactionaries', that is, the social democrats, the PSI, and economists such as Sumitro Djojohadikusumo, had taken over

meninggalkan azas "Negara Hukum" jang kita peladjari dari Belanda, dan dengan tidak meninggalkan hukum itu kita sekarang sedang menudju kesuatu "Negara Administratif", jaitu pandangan kenegaraan jang paling modern, dalam mana negara itu dipandang sebagai salah satu bentuk pengusahaan (Ondernemingsvorm), sedang didalam rangka pandangan "Negara Hukum" kewadjiban pokok dari Pemerintah hanjalah memelihara "keamanan dan ketertiban", sedang didalam "Negara Administratif" Pemerintah ikut aktif menjelenggarakan usaha2 untuk memperbesar kemakmuran masjarakat dan Negara. Dengan perkataan lain, dengan keputusan Pemerintah itu kita lebih tegas lagi menudju dari "Legal State" ke "Administrative State on Legal Basis" [...].'

90 Sukarno, 'Manifesto Politik Republik Indonesia', in Tudjuh Bahan Pokok Indoktrinasi (Jakarta: Panitia Pembina Djiwa Revolusi, 1963), 19. 'Bumi mendjadi subur untuk bertumbuhnja segala matjam aliran konvensionil, konservatif reaksioner dan kontrarevolusioner serta liberalism.' 
the country and divided the government from its leadership. In the words of Sukarno:

The head of the revolution is separated from the head of government. The head of the government in fact weakens the head of the revolution. He becomes nothing more than a 'stamp machine'. He often clashes with the ideology of the head of government. He has been 'trias-politica-ized', and not only within the executive. He has become Togog. ${ }^{91}$ This, according to supporters of the system, is said to be the highest of wisdom within democracy. Yes! Liberal democracy! Dutch democracy! The democracy of the Western states, whose democracy was born to the mother of middleclass capitalism (burgerlijk kapitalisme). ${ }^{92}$

This was an unconventional revolution and as a result, required unconventional means: 'It cannot be solved with means taken from the decrepit warehouse of liberalism. It cannot be solved with the means written in the textbooks of yore. 93

Sukarno was adamant that his revolution was 'modern' and, in this regard, he considered the changes brought about by the revolution to be both modern and anti-liberal. The cleansing of the contra-revolutionary was to happen through what was called retooling, a managerial strategy in which people were evaluated on the basis of their position in the revolution and replaced accordingly. Only those who were pro-revolutionary were allowed to participate. A whole slew of institutions would be created in order to achieve the goals of retooling.

91 A character in a wayang shadow play, the son of Semar, who had failed to be born, that is, his power was denied to him.

92 Sukarno, Djalannja Revolusi Kita (Djarek), 38-9. 'Pimpinan revolusi dipisahkan daripada pimpinan pemerintahan. Pimpinan Revolusi malahan dilumpuhkan (diverlamd-kan) oleh pimpinan Pemerintahan. Ia kadang-kadang didjadikan sekedar "tukang stempel". Ia sering sekali tabrakan faham dengan pimpinan Pemerintahan. Ia di-'triaspolitica'-kan bukan sadja, tetapi dalam bagian eksekutif daripada triaspolitica itupun ia sekedar didjadikan sematjam togog. Ini, menurut pentolan-pentolan sistim itu, dinamakan "hoogstewijsheid" dalam alam demokrasi. Ja! Demokrasi liberalisme! Demokrasinja Belanda! Demokrasinja negara-negara Barat, jang an sich demokrasi disana itu adalah anakkandung dan ibu kandung daripada burgerlijk kapitalisme.'

93 Sukarno, 'Penemuan Kembali Revolusi Kita', Pidato Presiden Republik Indonesia pada Hari Proklamasi 17 Agustus, 1959, 73. 'Ta' dapat ia diselesaikan dengan tjara-tjara jang keluar dari gudang-apeknja liberalisme. Ta dapat ia diselesaikan dengan tjara-tjara jang tertulis dalam text-booknja kaum sardjana dari zaman baheula'. 
Second, the Indonesian revolutionary leadership needed to pool together the 'funds and forces of the people'. Sukarno understood that, as a result of modern technological changes, the nature of participation had changed profoundly: 'In this twentieth century, with its sophisticated communication technology, every revolution is a people's revolution, a mass revolution, not like those of the previous centuries, when the revolution was often limited to the upper classes, the revolution of the ruling few. ${ }^{\prime 4}$ Thus, the revolution in question had a historical inevitability to it and an almost scientific and natural character. It was a revolution that involved three-quarters of humanity. 'Look and observe! A state that does not mature in a revolutionary fashion will not only be crushed by its own people, it will be swept clean by the universal revolutionary typhoon that is the most significant phenomenon of the present age. 95 The revolution was thus not only modern, but also in tune with global changes.

The importance of the participation of the masses was described succinctly as being part of the participative development that Guided Democracy promised. 'Universal development cannot succeed without mobilizing universal work. The revolution cannot work without the participation of the people in it. ${ }^{\prime 96}$ In order for the revolution to succeed, therefore, the relationship between the administrator and the masses had to change profoundly:

I stressed this in my Political Manifesto speech about the summoning of the energy and passion of the people because many of the people within the state apparatuses - the people with noble qualities - do not understand the meaning of mass energy and mass passion, and in fact suffer from a phobia of the masses and the people. The spirit of these noblemen and noble women must be cleansed and destroyed, so that the revolution

94 Sukarno, 'Penemuan Kembali Revolusi Kita', Pidato Presiden Republik Indonesia, 72. 'Dalam abad ke-xx ini, dengan ia punja teknik-perhubungan jang tinggi, tiap revolusi adalah revolusi Rakjat, revolusi Massa, bukan sebagai diabad-abad jang lalu, jang revolusirevolusinja adalah sering sekali revolusinja segundukan manusia-atasan sadja - "the revolution of the ruling few"'.

95 Sukarno, 'Djalannja Revolusi kita (Djarek). Amanat Presiden Republik Indonesia pada Hari Proklamasi 17 Agustus, 196o', 38. 'Lihat dan perhatikan! Suatu Negara jang tidak bertumbuh setjara revolusioner, tidak sadja akan digilas oleh Rakjatnja sendiri, tetapi djuga nanti akan disapu oleh Taufan Revolusi Universil jang merupakan phenomenon terpenting daripada dunia dewasa ini.'

96 Sukarno, 'Djalannja Revolusi kita (Djarek). Amanat Presiden Republik Indonesia pada Hari Proklamasi 17 Agustus, 196o', 72. 'sebab pembangunan semesta ta' mungkin berdjalan penuh tanpa ikut-ber-Revolusinja seluruh Rakjat. 
can continue as a People's Revolution and thus reach an optimal level of efficiency! 97

Sukarno's visit to China in 1956 must have had an important influence on this image of a united people working together under the guidance of revolutionary leadership. ${ }^{98}$ According to Sukarno, China had implemented a developmental programme that was contextualized within the history, culture, and character of the nation. China's industrialization programme had mesmerized him during his visit to the country. Chinese industrialization was driven not through foreign investment but through a revolutionary reordering of the productive powers of society, which appealed to him immensely. It was perhaps no coincidence that Mao's Great Leap Forward occurred at just about the same time as the introduction of Sukarno's Guided Democracy. ${ }^{99}$

Third, it was a planned and coordinated revolution. The planned nature of the revolution was essential. 'Planning is an absolute requirement for the implementation of socialism! Thus the implementation can then be divided between Guided Economy and Guided Democracy.'100 The revolution was a planned political, economic, social, cultural, and mental activity. The people, through organizations such as Depernas, created the plans, but their

97 Sukarno, 'Djalannja Revolusi kita (Djarek). Amanat Presiden Republik Indonesia pada hari Proklamasi 17 Agustus, 196o', 72-3. 'Saja mengulangi bagian pidato Manifesto Politik jang mengenai penggalangan tenaga dan semangat massa Rakjat ini in extensor (dengan lengkap), oleh karena masih banjak orang-orang dalam kalangan aparatur Negara orang-orang dengan kwalit eit ndoro-ndoro dan djuragan-djuragan, wanita-wanita dengan kwaliteit den-adjeng den-adjeng dan den-aju-den-aju - jang tidak mengerti artinja tenaga massa dan semangat massa, bahkan menderita penjakit massa-phobi dan Rakjat phobi, jaitu takut kepada massa dan takut kepada Rakjat. Djiwa ndoro dan djiwa den-aju itu harus kita tjutji sama sekali dan harus kita kikis sama sekali, agar supaja Revolusi dapat berdjalan benar-benar sebagai Revolusi Rakjat, dan oleh sebabnja berdjalan seeffisien-effisiennja pula!'

98 Sukarno, 'Amanat Pembangunan Presiden, 28 Agustus 1959', in Tudjuh Bahan Pokok Indoktrinasi (Jakarta: Panitia Pembina Djiwa Revolusi, 1963).

99 In comparison to the failure of Guided Democracy, the Great Leap Forward was successful at least in terms of the ability of the Chinese Communist Party to mobilize the people. This, of course, resulted in a massive tragedy as the indigenous industrialization process resulted in the loss of millions of lives. It may perhaps have been a lucky thing for Indonesia to have had such a weak bureaucracy, for the state could not, even if it had wanted to, have implemented such massive programmes that would have been prone to violence.

100 Sukarno, 'Djalannja Revolusi kita (Djarek). Amanat Presiden Republik Indonesia pada hari Proklamasi 17 Agustus, 196o', 59. 'Perentjanaan Pola, atau Planning, adalah satu sjarat mutlak bagi pelaksanaan Sosialisme! Planning itu nanti dalam pengkarjaannja mendjadilah wahananja Ekonomi Terpimpin dan Demokrasi Terpimpin.' 
implementation was to be guided by the revolutionary leadership. This was the last but perhaps one of the most important components of the revolution, for, in order for it to succeed, it had to be guided by the leadership. 'In the absence of leadership, without the provision of planning in each of the complex parts of the revolution, we would reach, as I have said before, a multi-complex chaos.'101

The revolution was rooted in the changing nature of the relationship between the people/masses and its leadership. The revolution thus shared its roots with the democratic expansion of participation. 'The foundation and goal of the Indonesian revolution is congruent to the Social Conscience of Man!. ${ }^{102}$ Social justice, individual freedom and national freedom were the goal that was espoused by Sukarno during the formation of Indonesia's national ideology and principles, the Pancasila, in 1945. 'It is not a Western democracy, but a political-economic democracy, a political democracy with social justice (sociale rechtvaardigheid), a democracy with welfare; those two notions I squeeze into one. This is what I have always called a socio-democracy.'103

This focus on social justice and welfare promoted by the state was contrasted with a liberal notion of statehood. For the state to actually act in ways that would promote social justice and welfare, the executive was required to have the ability to act outside the boundaries that had been set up as part of the separation of powers. In the words of Utrecht:

The granting of 'Freies Ermessen'104 to the state administration meant that some of the power held by the Parliament, by the legislative body, has been transferred to the hands of the government, the administration, as the executive body. This is something that occurs in all 'welfare states'

101 Sukarno, 'Amanat Presiden tentang Pembangunan Semesta Berentjana. Sidang Pleno Depernas, 28 Agustus 1959', 6o. 'Djikalau tidak diberi pimpinan, tidak diberi planning dimasing-masing bidang dari kompleksiteit daripada revolusi ini, maka kita achirnja sebagai tadi sudah saja katakan, datang kepada kompleksiteit kekatjauan.'

102 Sukarno, 'Penemuan Kembali Revolusi Kita', Pidato Presiden Republik Indonesia, 41. 'Dasar dan tudjuan Revolusi Indonesia adalah congruen dengan Social Conscience of Man itu! Keadilan sosial, kemerdekaan individu, kemerdekaan bangsa dan lain sebagainja itu adalah pengedja-wantahan daripada Social Conscience of Man itu'.

103 Sukarno, 'Lahirnja Pantjasila, 1947' in Tudjuh Bahan Pokok Indoktrinasi (Jakarta: Panitia Pembina Djiwa Revolusi, 1963), 29. 'Dan Demokrasi jang bukan demokrasi Barat, tetapi politiek-economische democratie, jaitu politieke democratie dengans sociale rechtvaardigheid, demokrasi dengan kesedjahteraan, saja peraskan pula mendjadi satu. Inilah jang dahulu saja namakan socio-democratie.'

104 Discretionary power or pouvoir discretionaire or beoordelingsvrijheid. It has become an essential component in Indonesian administrative legal theory. 
as a logical consequence of the implementation of said 'welfare state'. By expanding the power of the executive, the concept of the guided democracy is born as the system of government of the welfare state. ${ }^{105}$

This executive expansion was a worrying aspect of the administrative state in relation to democracy and it was something that had been bothering people both in the West and in Indonesia. 'Differing from the narrow definition of the legal state (Kant, Fichte), the 'idea of the modern legal state does not emphasize the law (positive law), but the goal of social justice (sociale gerechtigheid) to all citizens. If necessary, the state can act outside of the law in order to reach that social justice. ${ }^{\prime 106}$ The 'welfare state' thus expanded the discretionary power of the executive. ${ }^{107}$

In fact, leaving behind the trias politica was a phenomenon that transcended the ideological divide of the Cold War. In his discussion on public administration, Utrecht considered the various new ideas surrounding the shift from a separation of powers to a separation of functions: 'The separation was present in the discussions of three famous American experts who have studied "Government" and "Public Administration", namely Woodrow Wilson, Frank Goodnow, and Herman Finer.'108 Obviously the rise of the welfare state in the West had not resulted in the rise of military dictatorships. Sukarno was adamant that the revolution was essentially democratic; he saw its genesis to be

105 Ernst Utrecht, Pengantar dalam Hukum Administrasi Negara Indonesia (Jakarta: Ichtiar, 1963), 23. 'Diberinja "freies Ermessen" kepada administrasi negara itu sebenarnja berarti bahwa sebagian kekuasaan jang dipegang oleh dewan perwakilan rakjat, sebagai badan legislatif, dipindahkan kedalam tangan pemerintah, administrasi negara, sebagai badan eksekutif. Hal ini mendjadi kenjataan ditiap-tiap "welfare State" sebagai suatu konsekwensi logis dari diadakannja "welfare State" itu: supremasi badan legislatif diganti oleh supremasi badan eksekutif! Ekonomi terpimpin, sebagai sistim perekonomian "welfare State", - sebagai suatu konsekwensi logis - memperbesar kekuasaan eksekutif, melahirkan demokrasi terpimpin sebagai sistim pemerintahan "welfare State".'

106 Utrecht, Administrasi Negara Indonesia, 35. 'Berlainan dengan "idee" negara hukum dalam arti kata sempit (Kant, Fichte), maka dalam "idee" negara hukum modern titik-berat pada pokoknja tidak terletak pada "hukum" (hukum positif), tetapi pada tudjuan mentjapai keadilan sosial (sociale gerechtigheid) bagi semua warga negara. Apabila perlu, negara djuga boleh bertindak diluar hukum untuk dapat mentjapai keadilan sosial bagi semua warga negara itu.'

107 Some legal experts considered it the end of the law-based state when Sukarno gave ministerial status to the head of the Supreme Court in 1961. Reksohadiprodjo, 'The Relations of Law and Economic Development', 33 .

108 Utrecht, Administrasi Negara Indonesia, 34. 'Pembagian tersebut terdapat dalam tiga ahli terkemuka bangsa Amerika Serikat jang mempeladjari "Government" dan "Public Administration”, jaitu Woodrow Wilson, Frank Goodnow dan Herman Finer.' 
Western but more perfect, claiming as antecedents both the French and American bourgeois revolutions and the Marxist Russian revolution. Leaving behind the separation of powers, alongside the decimation of the legislative body and its party elements, the revolution also signalled a significant lurch towards the creation of a military dictatorship. Even if the Guided Democracy never became an outright dictatorship, it did provide the principles and groundwork for one.

It is also important to understand that the foundation of the Guided Democracy and Guided Economy state, Indonesia's constitutional ideology, did not particularly conflict with ideas surrounding the rise of the administrative state. The Presidential Decree of 1959 (Dekrit Presiden 1959) was issued outside the bounds of the constitution but was justified as a logical consequence of the implementation of a welfare state (guided democracy)'109 in order to create executive supremacy over the legislative body. Sukarno used Article 22 of the 1945 Constitution (or Article 96 of the 1950 Constitution), which allowed for the creation of a government regulation in lieu of the constitution (peraturan Pemerintah pengganti undang-undang, or p.P.p.u.u.), which was justified in a 'situation of forced emergency'.110 Rather than using it for its intended purpose, however, he used it to justify the ending of parliamentary democracy by attacking the liberal straw man. Guided Democracy was depicted as a social philosophy that went with the times, whereas liberalism was painted as something that was conservative and unmodern. The only difference was that it was to be a managerial state that was at the same time revolutionary. The argument shown above was congruent with the arguments discussed in Chapter 1: the 1928 generation was now being garbed as the 'revolutionary leadership'.

As a result, the rise of the Guided Democracy state was not incompatible with the developments in public administration that had occurred during the 195os. The LAN was to occupy a relatively important position during the period, although it failed to take over leadership of the development of Indonesian public and business administration education. ${ }^{111}$ The Guided Democracy's rise was not predicated on any form of East-West divide but, rather, on an almost mythical divide between liberalism and socialism. As Utrecht's discussion of the rise of the public administration in Indonesia shows, its roots were entirely Western, that is, American. That said, Utrecht did also discuss the German and Dutch cases and their own 'Americanization' during the period, especially the

109 Utrecht, Administrasi Negara Indonesia, 26.

110 Utrecht, Administrasi Negara Indonesia, 23.

111 Djuna Hadisumarto, 'The Indonesian Civil Service and its Reform Movement', PhD dissertation, Indiana University, Bloomington, 1974, 182-3. 
thoughts of Dutch legal specialist O. M. Donner and management specialist Gerrit van Poelje.12

The conflict between democracy and efficiency was the main divider between what Waldo, writing in the 1940s, termed 'progressives', who advocated planning, and the 'old-liberals', who believed that efficiency could only be achieved if more democracy were introduced. In Waldo's words: 'They knew that the Future must well up from below. In opposition were those whose patience was exhausted waiting for the Promise of American Life to realize itself by natural and inevitable means, whose view of human nature was not so charitable and who had no faith in the devices of primitive democracy, who had begun to think of planning and who realized that builders need tools. ${ }^{113}$ The ambivalence towards democracy was partially based on the disdain that the manager had for the legal process. 'The anti-legal temper of public administration is obvious and its import clear. In fact, one does not need to go far in the literature of public administration to find that if any person is to count for less than one in the New Order it is the lawyer! The lawyer suffers from a meager social outlook, the spirit of the New Management does not abide with him.'114

Yet, the image of the welfare state was exemplified by the success stories of the Western European and North American democracies. The welfare state became a symbol of the success of the West. There was no doubt that people like Waldo, Burnham, ${ }^{115}$ and Redford, ${ }^{116}$ who had ruminated on the potentially autocratic nature of the state in question, saw the inherent problem in finding the balance between individualism and democracy and the welfare state. In fact, many of the analyses of public administration in the United States

\footnotetext{
112 Donner's idea, understood in Indonesia as dwipradja, divided the government along functional lines between those who determine the function of government duties (taakstelling), that is, policymakers, and those who implement the duties (verwezenlijking van de taak). This was in line with Woodrow Wilson's division into Government, as the political arm that determines policies, and Public Administration, which implements the policies in question.

113 Waldo, The Administrative State, 18.

114 Waldo, The Administrative State, 79.

115 Burnham, The Managerial Revolution.

116 E. S. Redford, Democracy in the Administrative State (New York: Oxford University Press, 1969).
} 
focused on reconciling the problem between the ideals of individualism and democracy and the expansion of an efficient state. ${ }^{117}$

The strength of the commitment to the rule of law was related to the state-society ideology that the nation prescribed for itself. In this case, it could be argued that the American value of individualism, rooted in a tradition of economic independence, allowed for critical opposition that functioned as a check on the expansion of the administrative state. This 'liberal' opposition was practically non-existent in Indonesia. Rule of law was considered a bourgeois belief that masked the class roots of the law under objective and neutralist notions. As Suprapto phrased it, "The theory of the law and the state, which is a formalistic, logical-formal abstract, instructs the creation of the law for the "vested interests", to maintain a state without justice (Staat ohne Recht). ${ }^{\prime 18}$ Even a legal specialist like Ernst Utrecht, who tried to argue for the relevancy and importance of at least administrative law, did not particularly posit the rule of law as an inherently central component of democracy. Similar to the communists' attack on the economic science taught by 'Sumitro-followers', the Marxist legal approach was to see the law as inherently bound up with the class struggle. ${ }^{119}$ Jusuf Adjitorop, a member of the politbureau and secretary of the PKI, said that the main issue for national law was 'how to integrate the work of the legal specialist with that of the masses.'120

It was important that the law was revolutionized in order to reflect the changing values of the new ruling class. The role of national law was to raise awareness of Indonesian socialism and gotong rojong values, and to push for more equitable production methods for a just society. ${ }^{121}$ Utrecht was a member of the National Law Development Institute (Lembaga Pembinaan Hukum Nasional), created in 1958 as part of the Guided Democracy revolution. In a seminar on national law held in 1963 by the institute, Suprapto, a legal specialist, explained the idea of the law as understood under Guided Democracy:

117 For instance, Redford, Democracy in the Administrative State and F. C. Mosher, Democracy and the Public Service (New York: Oxford University Press, 1968).

118 Suprapto, Dasar Pokok, Fungsi, Sifat2 dan Bentuk Hukum Nasional (Jakarta: Lembaga Pembinaan Hukum Nasional, 1963), 8. '[...] teori tentang hukum dan negara jang formalistis, logis-formil-abstrak, itu mengadjarkan untuk menegakkan hukum bagi kaum "vested interest", untuk mempertahankan negara tanpa keadilan (Staat ohne Recht).'

119 Ernst Utrecht, Pengantar dalam Hukum Indonesia (Jakarta: Ichtiar, 1964), 230 and 306.

120 Jusuf Adjitorop, Peranan dan Tugas2 Hukum Nasional dalam Alam Manipol (Jakarta: Jajasan Pembaruan, 1963), 6.

121 Suprapto, Dasar Pokok, Fungsi, Sifat2 dan Bentuk Hukum Nasional, 15. 
Until now the influence of formalism on a theory of law based on a static, abstract way of thinking, with narrow formal logics, known as 'beslissing leer,' 'theorie van stelligstaatsrecht' and so forth, has not been able to be fully removed from the science of Dutch legal knowledge. Basically, these theories intend to separate the law from its relationship with the entirety of social and individual life in all its myriad forms, which affect and are affected by one another, always moving and contradicting, with their own dynamics of change through the process of evolution and revolution and creating qualitative and quantitative exchanges. The theory of law that says that the law is the result of the abstraction of a decision made by officials appointed by the state, and that the state is merely an organization composed of a series of functions, a formalism needed by the colonialist to protect the vested interests of the monopolist and feudalist, of the landlords and other bloodsuckers. ${ }^{122}$

Individualism was seen as anathema to the ideals of Indonesian society. During the constitutional discussions in 1945 , which gave birth to the national ideology, the conservative nationalist leadership chose to use the indigenous legal code (Herziene Inlandsche/Indonesische Reglement, HIR) as opposed to the European legal code. The HIR had fewer provisions in place to protect the legal subjects. According to Lev, the logic of colonial law 'had mainly to do with maintaining a manageable mass of Indonesians in place.123 During the Japanese occupation, many of Indonesia's nationalist leaders had worked in the administration. In a meeting with Sukarno, the head of the military in

122 Suprapto, Dasar Pokok, Fungsi, Sifat2 dan Bentuk Hukum Nasional, 7. 'Sampai pada saat ini masih belum dapat dihapuskan seluruhnja pengaruh formalisme daripada teori hukum jang didasarkan pada tjara berfikir abstrak jang statis, logika formil jang sempit, sebagai jang terkenal dengan nama "beslissingen leer", "theorie van stellig staatsrecht" dsb. Dari dunia ilmu pengetahuan hukum Belanda. Dalam hakekatnja teori-teori tadi hendaknja melepaskan hukum dari hubungannja dengan keseluruhan kehidupan masjarakat dan individu dalam berbagai-bagai seginja, jang saling berhubungan dan saling mempengaruhi, jang senantiasa bergerak dan saling berkontradiksi dan jang dengan dinamikanja sendiri berobah melalui evolusi dan revolusi, dengan menimbulkan pertukaran kwalitas dan kwantitas. Teori hukum jang mengadjarkan, bahwa hukum adalah hasil pengabstrakan dengan pikiran dari keputusan-keputusan jang dibuat oleh pedjabat-pedjabat jang ditundjuk oleh negara dan negara tak lain hanjalah suatu organisasi jang terdiri daripada rangkaian fungsi-fungsi adalah suatu bentuk formalisme jang diperlukan oleh kaum pendjadjah untuk mempertahankan "vested interest" kaum modal monopoli dan golongan feodal, golongan tuan tanah dan kaum penghisap lainnja.'

123 Daniel Lev, Legal Evolution and Political Authority in Indonesia. Selected Essays (The Hague: Kluwer Law International, 2000), 19. 
Java, General Imamura, had personally stated his support for the employment of as many Indonesians within the government as possible. ${ }^{124}$ Perhaps one of the most significant effects of the Japanese occupation was the promotion of a world view based on a deep and inherent suspicion and dislike of Western imperialism and its replacement with a corporatist economic order, one called Hakko Ichiu, which positioned the 'Eastern' concept of the family as the governing principle in understanding state-society relations. ${ }^{125}$

\section{Conclusion}

Understanding the ideological developments of the 1950s is essential to understanding the changes that occurred from the late 1950s as the Guided Democracy emerged. The process of Americanization inadvertently led to the importation of scientific management, whose Indonesian incarnation prompted an ideological shift. This allowed the rise of a pre-independence corporatist notion, which had been written into the earlier 1945 Constitution, to join forces with the efficiency mantra that drove the interest in scientific management. This resulted in a reordering of state-society relations that was congruent with corporatism and the idea of the welfare state.

The rise of a new Indonesian managerial class was a component in the structural changes that occurred with the creation of national planning. The expansion of the roles played by these new managers - graduates of the management education provided during the decade, as well as military officers who had obtained managerial posts within the government and the economy - required the reordering of the economy and wider society. In order to achieve this, a national planning scheme was created as part of the Indonesian revolution. It is on this national planning and structural transformation that the next chapter focuses its attention. These were essential components that complemented the shift in ideas that was inadvertently introduced as a result of the expansion of scientific management.

124 Mitsuo Nakamura, 'General Imamura and the Early Period of Japanese Occupation', Indonesia, 10 (October 1979), 1-26.

125 On the basic objectives of establishing a New Economic Order for the people of Java (Jawa jumin keizai shintai seiken setsu no kompon shushini tsuite), see Harry J. Benda, James K. Irikura and Koichi Kishi, Japanese Military Administration in Indonesia: Selected Documents (Ithaca: Southeast Asia Studies, 1965), 113. 